University of Puget Sound

Sound Ideas

Summer Research

Summer 2021

\title{
Petrology and Tectonic Setting of the Silver Pass Volcanics, Central Cascades, WA: Early Evidence of Farallon Slab Breakoff
}

\author{
Pauline Peterson \\ University of Puget Sound \\ Jeff Tepper \\ University of Puget Sound
}

Follow this and additional works at: https://soundideas.pugetsound.edu/summer_research

\section{Recommended Citation}

Peterson, Pauline and Tepper, Jeff, "Petrology and Tectonic Setting of the Silver Pass Volcanics, Central Cascades, WA: Early Evidence of Farallon Slab Breakoff" (2021). Summer Research. 417.

https://soundideas.pugetsound.edu/summer_research/417

This Article is brought to you for free and open access by Sound Ideas. It has been accepted for inclusion in Summer Research by an authorized administrator of Sound Ideas. For more information, please contact soundideas@pugetsound.edu. 


\section{Petrology and Tectonic Setting of the Silver Pass Volcanics, Central Cascades, WA: Early Evidence of Farallon Slab Breakoff}

\section{Introduction}

Subduction has been occurring off the coast of North America for approximately 200 million years, but during the middle Eocene ( $\sim 50 \mathrm{Ma})$, the subducting Farallon plate broke off, producing a belt of igneous rocks that extends across presentday central Washington.

The Silver Pass Volcanics (SPV) are of the right age and location to be a product of slab breakoff and this study seeks to place them in the larger geologic context of this event.

\section{Geological Setting}

- During the Middle Eocene (55-45 Ma), accretion of the Siletzia terrane slowed and eventually stopped low-angle subduction of the Farallon plate (Tabor et. al., 1982). - Subsequently, the Farallon plate rolled back and broke off and this event is recorded by a NNW trending belt of volcanic rocks that extends for $>150 \mathrm{~km}$ in Western Washington (Kant et. al., 2018) [Fig. 1]

- Subduction of the Juan de Fuca plate resumed $\sim 45 \mathrm{Ma}$ creating the modern Cascade arc.

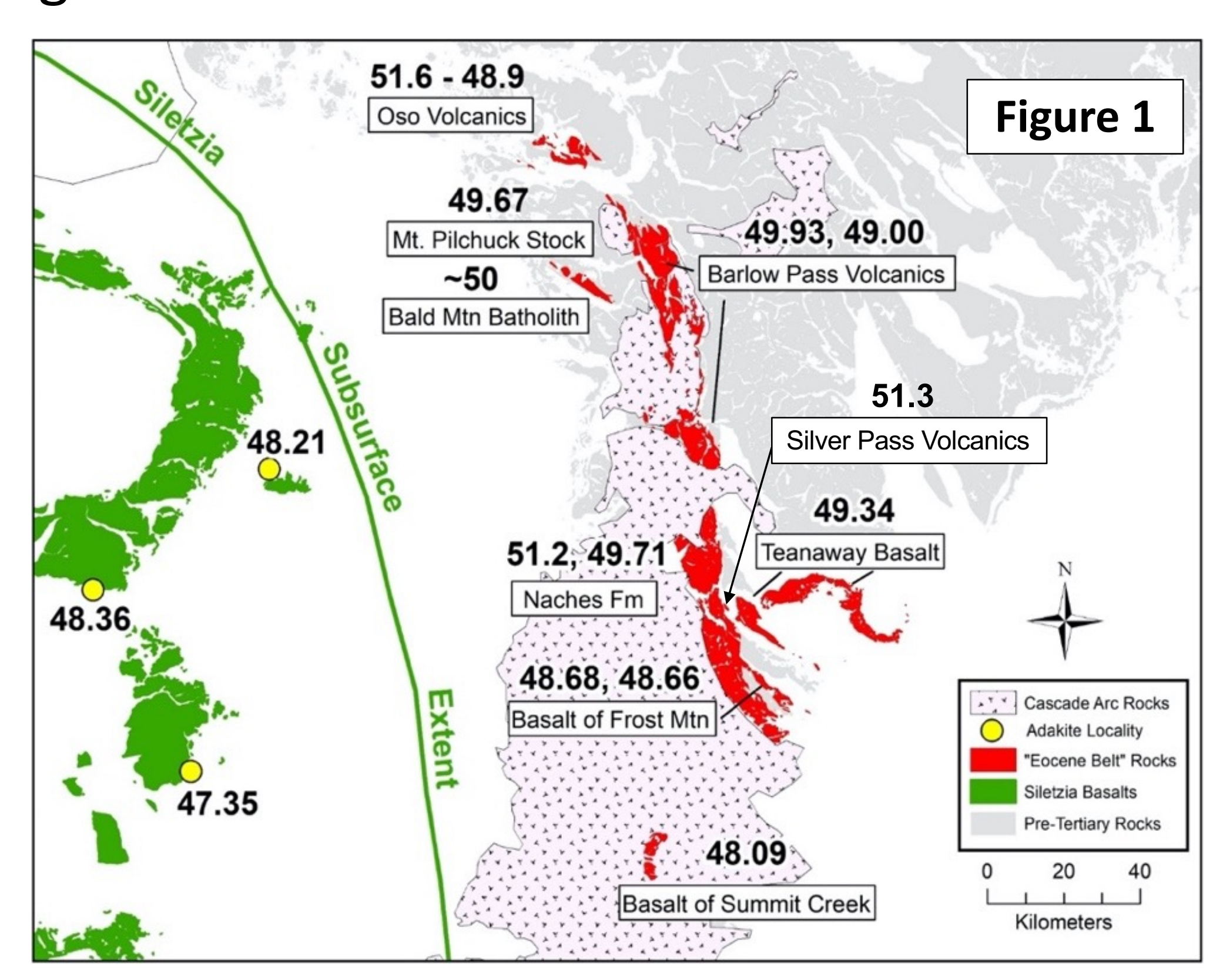

\section{Field Relations}

The SPV consist of $\sim 3600$ feet andesite and dacite lava flows along with tuffs and breccias that have been folded into a syncline with limbs that dip NE and SW [Figs. 2-4] (Lofgren, 1973).

Peperites indicate some eruptions occurred in shallow water [Fig. 3]
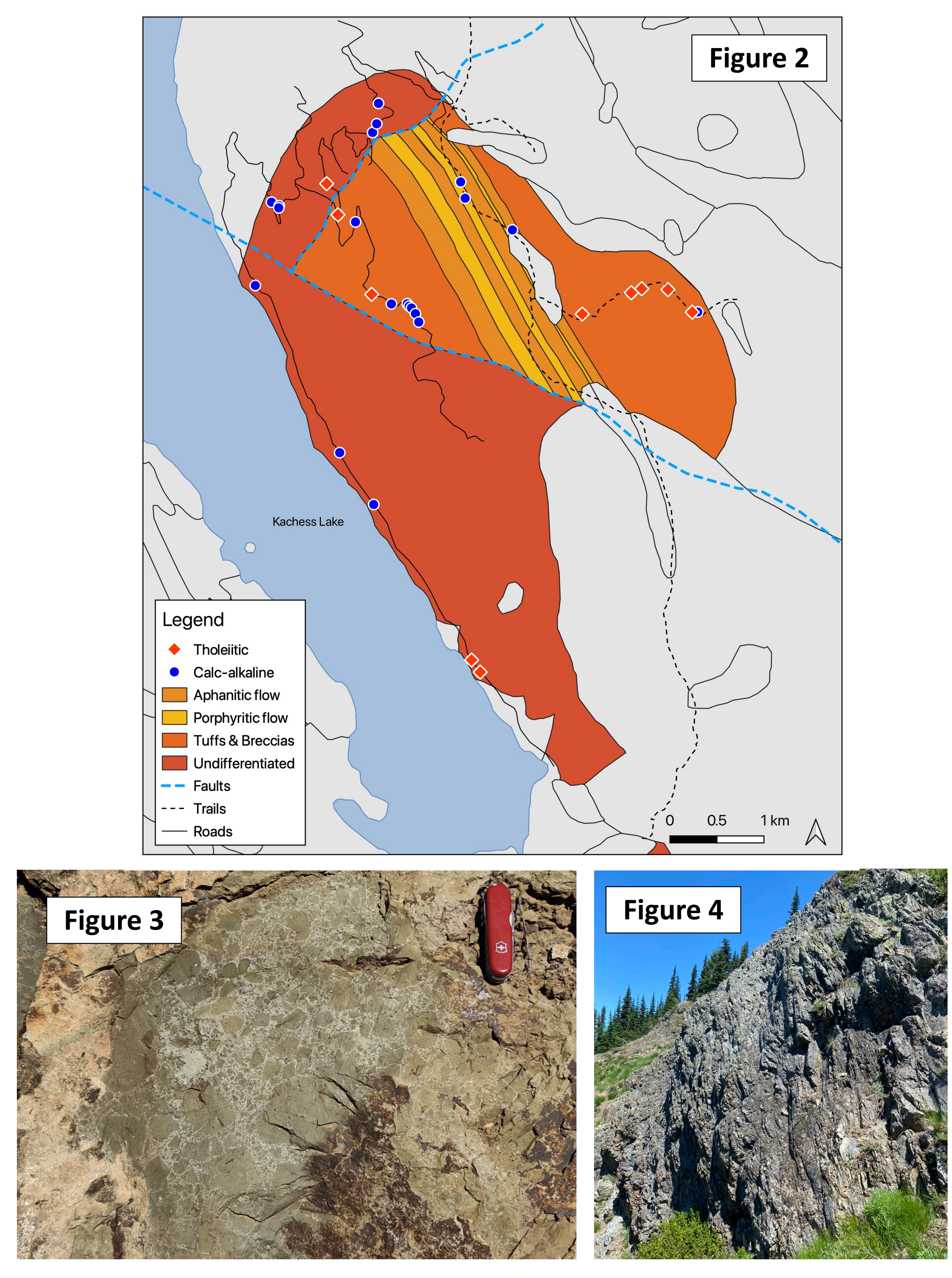

\section{Geochemistry}

- 32 samples were collected from outcrops along logging roads and hiking trails [Fig. 2].

- SPV samples exhibit a full B-A-D-R suite [Fig. 5] and display trace element signatures typical of subduction zones including LILE enrichment and HFSE depletion [Fig. 6].
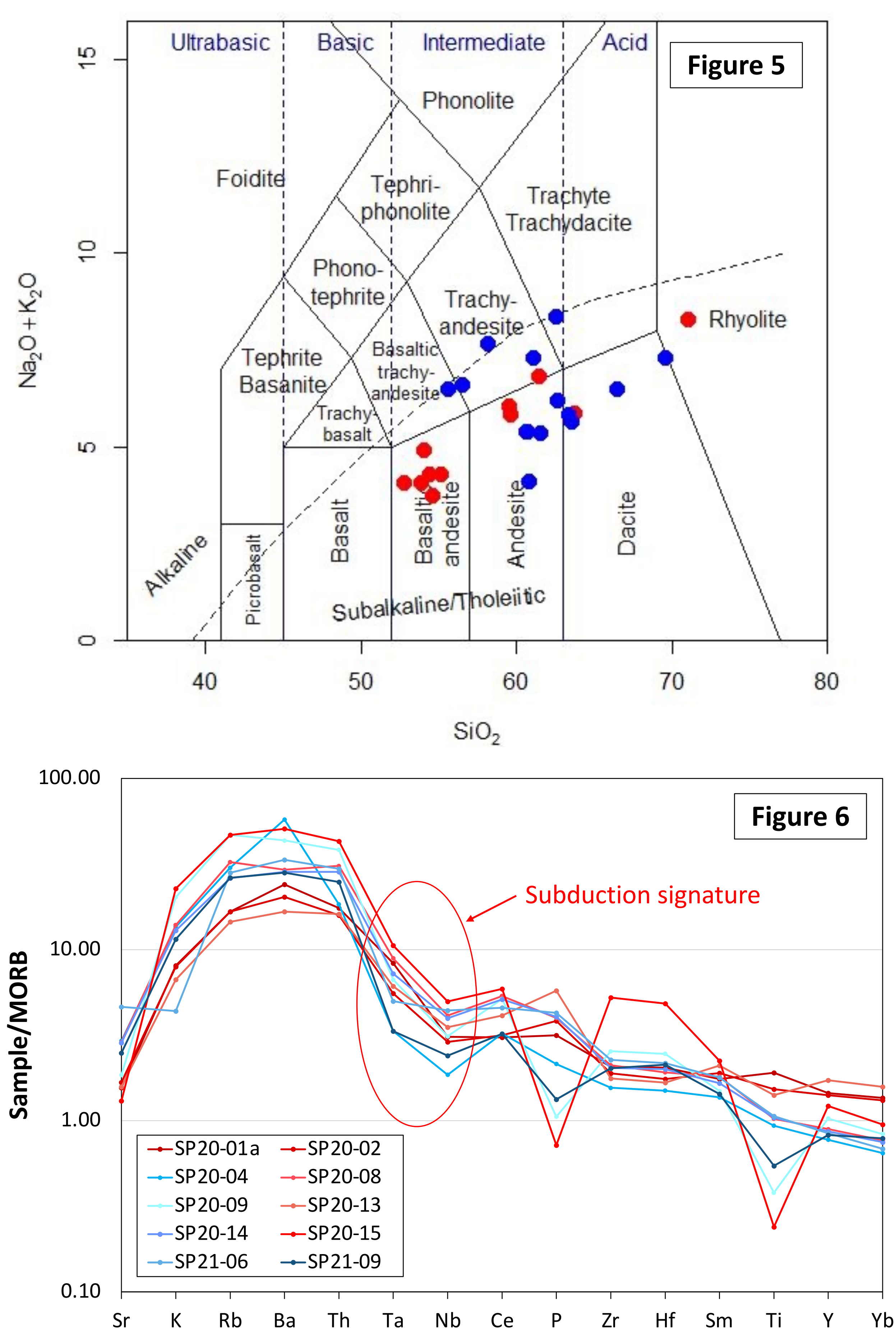

The SPV display two distinct magma series, distinguishable by a number of chemical characteristics [Table 1] [Figs. 7-9].

Group 1, or tholeiitic, lavas mainly occur low in the section, but some are interbedded with younger Group 2 lavas higher in the section [Fig. 2].

\begin{tabular}{|l|c|c|}
\hline Table 1 & Group 1 & Group 2 \\
\hline Magma Series [Fig. 8] & Tholeiitic & Calc-alkaline \\
\hline Rock Type [Fig. 5] & $\begin{array}{c}\text { Basaltic andesite- } \\
\text { andesite }\end{array}$ & Andesite-rhyolite \\
\hline SiO2 [Fig. 7] & $<55 \%$ & $>55 \%$ \\
\hline Average MgO [Fig. 8] & $1.9 \%$ & $2.9 \%$ \\
\hline Average Fe2O3 [Fig. 7] & $11.6 \%$ & $6.4 \%$ \\
\hline Average TiO2 [Fig. 10] & $1.6 \%$ & $1.1 \%$ \\
\hline La/YY [Fig. 9] & $<5$ & $>5$ \\
\hline
\end{tabular}
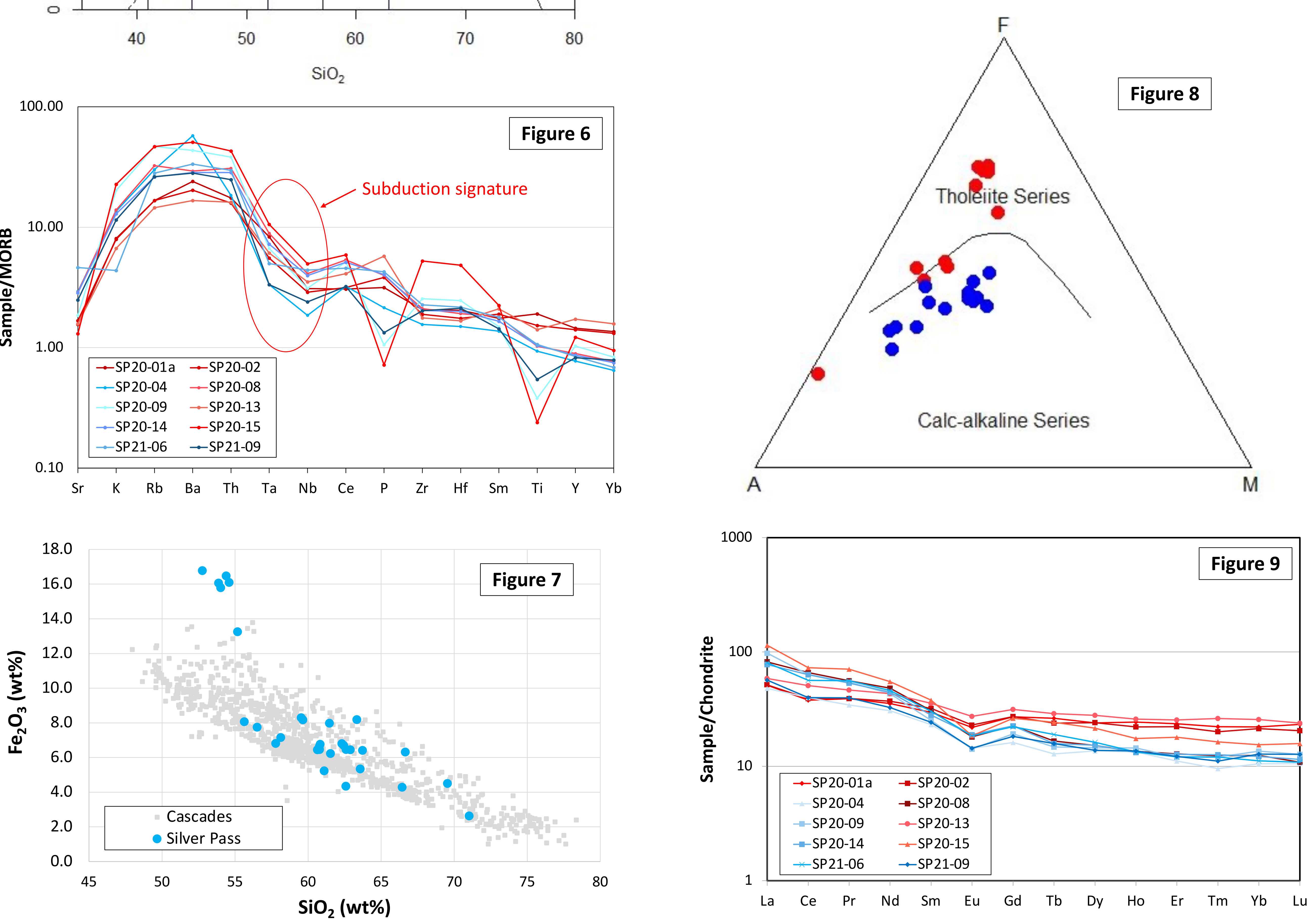

Silver Pass Volcanics vs. Taneum Formation

The Taneum Formation (TF) is located directly to the south of the SPV and is similar in age ( $\sim 48.3$ to $\sim 51.3$ $\mathrm{Ma})$, meaning the two units may be equivalent.

While the units are geochemically similar, the SPV are:

More iron rich (avg $\mathrm{Fe}_{2} \mathrm{O}_{3}=7.8$ vs. 5.9 wt.\%) [Fig. 10]

- Posses a weaker arc signature ( $\mathrm{Ba} / \mathrm{Nb}=62$ vs. 96)

The presence of adakites in the TF is an indication of melting at the edges of the slab tear. The SPV do not posses strong evidence of slab melting.

- Though the SPV and the TF are both the result of slab breakoff, their geochemical differences indicate that they likely formed from different eruptive centers.

\section{Tectonic Setting \& Conclusions}

- Geochemical traits, age, and location of the SPV indicate it was likely a part of the "breakoff belt" (Kant et al., 2018) [Figs. 1 \& 12]

Slab breakoff occurred in response to the accretion of Siletzia around $52 \mathrm{Ma}$ [Fig. 11].

The presence of both tholeiitic and calc-alkaline magma compositions reflects melting of two distinct mantle sources.

Tholeiitic rocks likely formed when hot mantle

(asthenosphere) rose from below the slab and underwent decompression melting.

- Tholeiitic rocks are found almost entirely in the lower part of the section, indicating decompression melting likely began first.

Calc-alkaline rocks originated from the overlying mantle wedge that had been affected by earlier subduction.

Calc-alkaline rocks tend to be younger and likely represent a later stage of melting.

Unlike other units in the breakoff belt, the SPV are not bimodal, indicating a more arc-like setting. This combination of arc and breakoff traits may be characteristic of the earliest stages of slab breakoff.
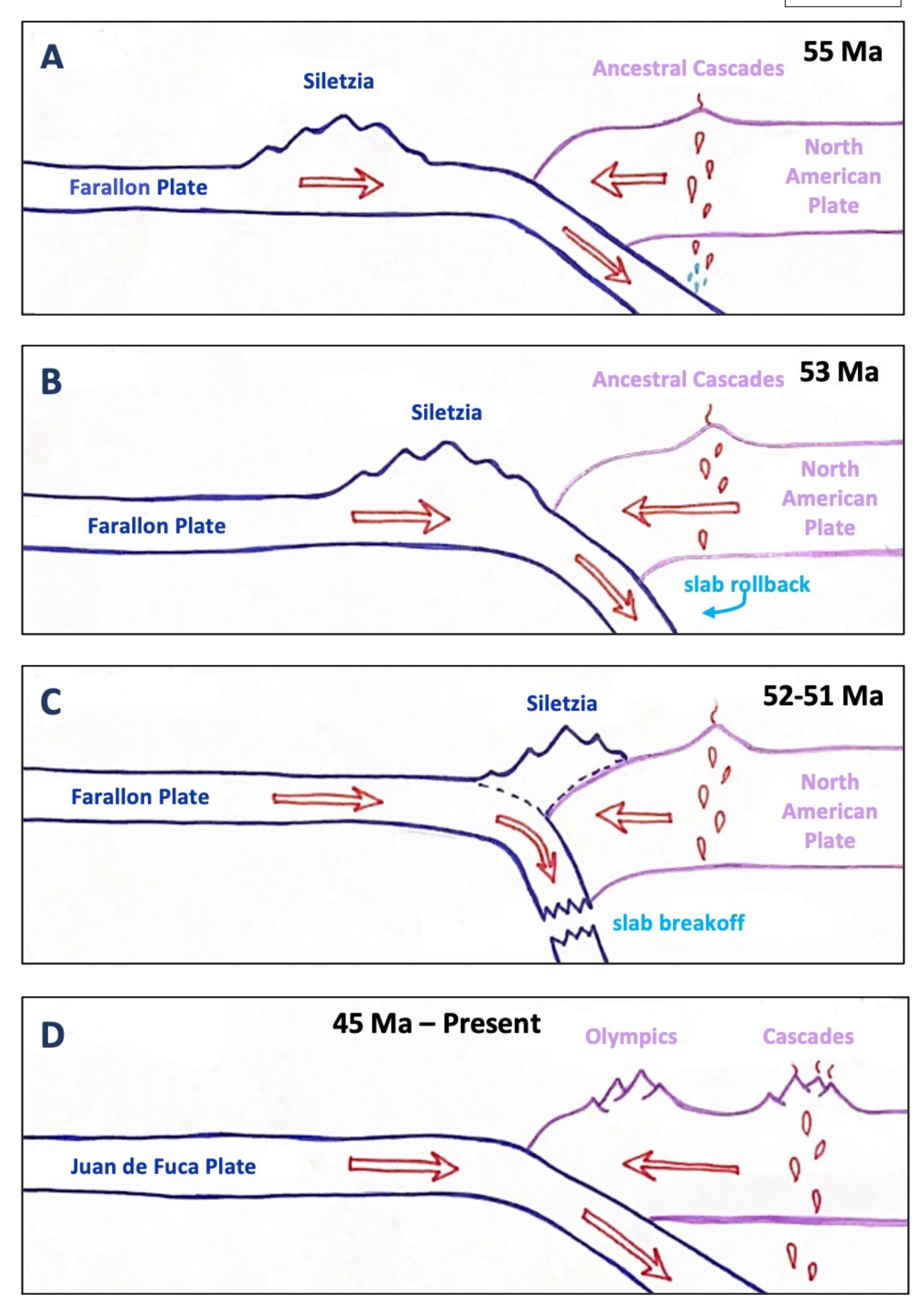

\section{Acknowledgements}

I would like to thank the University of Puget Sound Geology Department, Jeff Tepper and all the members of the Tepp Lab, and the Clare Boothe Luce Program for funding this project.

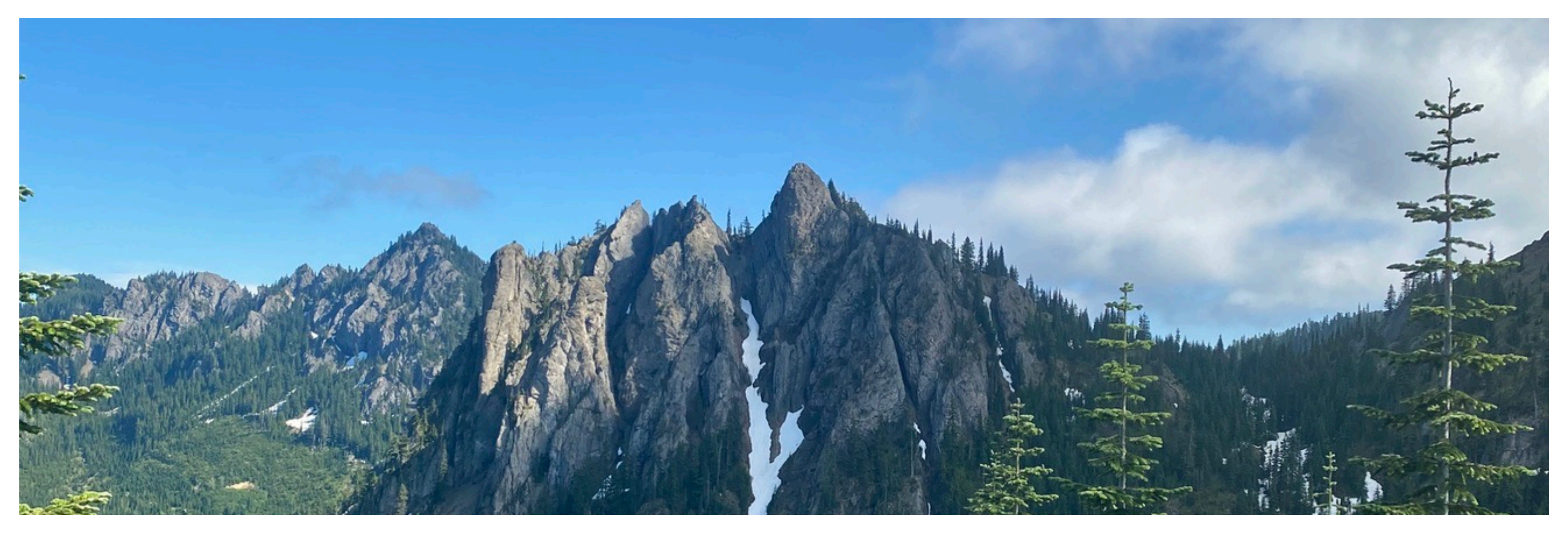

